\title{
THE ECONOMIC AND ECOLOGICAL POTENTIAL OF MACROPHYTIC VEGETATION IN URBAN LAKES
}

Oriana IRIMIA-HURDUGAN *

* “A. I. Cuza” University, Carol I Boulevard 11, Iaşi, Romania, RO-700506, oriana.irimia@gmail.com

DOI: 10.2478/trser-2013-0021

KEYWORDS: Macrophytes, urban lakes, Bucharest, fertiliser, fodder, integrated waste management, integrated lake management.

\begin{abstract}
This paper considers certain elements relating to the ecological and economic importance of the aquatic macrophytes common in the Câmpia Română/Romanian Plain lakes, especially those species belonging to the genera Myriophyllum and Potamogeton, common in Bucharest's urban lakes. At present, the macrophytes of the Bucharest lakes are collected by personnel of the Lakes, Parks and Leisure Administration of Bucharest by mechanised and manual methods, which are sun-dried and transported as waste and deposited in a landfill. Thus these macrophytes are merely generating costs through harvest, transport and storage, instead of being a direct revenue source for the City hall. This study presents a review of international literature in support of the economic potential as fertiliser for open field crop, orchard and garden crop application, as well as food for farm animals. The last portion of the paper argues the vital need for the preservation of macrophyte stands in the lacustrine habitat for green, sustainable and integrated management of the urban lakes used for leisure and fishing.

RÉSUMÉ: Le potentiel économique et écologique de la végétation macrophytique provenant des lacs urbains.

L'article présente les aspects de l'importance économique et écologique des espèces de plantes macrophytes communes, dans les lacs de la plaines roumaine, et particulièrement les espèces Myriophyllum et Potamogeton peuplant les lacs urbains de Bucarest. A présent, les macrophytes de ces lacs sont ramassés par le personnel de l'Administration des Lacs, Parcs et Loisirs de Bucarest par des moyens mécanisés ou à la main, séchés au soleil puis transportés à la déchèterie municipale. Ainsi les plantes génèrent uniquement des coûts de cueillette, transport et stockage, sans apporter de bénéfice économique direct. L'article recence quelques publications scientifiques internationales documentant l'usage des macrophytes comme engrais et protection pour les cultures, les vergers et les jardins ainsi qu'en tant que supplément nutritif pour les animaux de ferme. Ensuite, on présente la nécessité vitale de préserver quelques lopins de macrophytes dans les habitats lacustres afin d'assurer une gestion durable, écologique et intégrée des lacs utilisés pour les loisirs et la pêche.
\end{abstract}

REZUMAT: Potențialul economic și ecologic al vegetației macrofitice din lacurile urbane.

Prezenta lucrare abordează elemente legate de importanţa ecologică şi economică a speciilor de plante macrofite acvatice comune lacurilor din Câmpia Română, în special a speciilor din genul Myriophyllum şi Potamogeton, în cazul lacurilor urbane bucureştene. În prezent, macrofitele din lacurile din Bucureşti sunt recoltate de personalul Administraţiei Lacuri, Parcuri şi Agrement Bucureşti cu mijloace mecanizate sau manuale, deshidratate natural şi transportate la groapa de gunoi municipală ca deşeuri. Acest lucru face ca plantele să 
antreneze doar costuri substanţiale, de recoltare, de transport şi de depozitare, fără să aducă nici un beneficiu economic direct. Lucrarea constituie o trecere în revistă a publicațiilor științifice internaționale ce tratează utilizarea macrofitelor ca îngrăşământ şi protector de culturi de câmp, livadă şi grădină precum şi ca hrană pentru animale. Lucrarea tratează de asemenea necesitatea vitală a conservării unor parcele populate cu aceste plante în habitatul lacustru pentru o administrare ecologică, durabilă şi integrată a corpurilor de apă utilizate pentru agrement şi piscicultură cu argumente din date şi observaţii proprii.

\section{INTRODUCTION}

The most common macrophytes in Bucharest lakes are the milfoil Myriophyllum spicatum (Linné, 1753) Magnoliopsida, Saxifragales, Haloragidaceae and the curly-leaf pondweed Potamogeton crispus (Linné, 1753), Liliopsida, Najadales, Potamogetonaceae. These species colonise lakes such as Tineretului Lake, Lia Manoliu Lake or National Park Lake, Titan Park Lake, Tei Lake, Herăstrău Lake and the urban portion of the Dâmboviţa River channel. Potamogeton is the most commonly found macrophyte. Growing up to 3-4 m long, Potamogeton has many leaves and may cover entire lake surfaces, especially in urban lakes less than $2 \mathrm{~m}$ deep. This particular biotope forms a suitable habitat for migrating waterfowl that nest and feed on the leaves (especially the ducklings who consume them in large quantities). Underwater, an entire ecosystem has been established with macrophyte species of phytoplankton, zooplankton, epiphytes, water insects, Orthoptera larvae, arachnids, and predator coleopterans. There are also alevins of different fish species, in particular economically and ecologically interesting predators such as pike or perch, and the presence of turtles (Emys orbicularis, a CITES Convention protected and Romania's Red Book mentioned species, counts at least a dozen individuals in Tineretului Lake for instance) and amphibians (some of the species being protected by the law applying the CITES Convention). The milfoil is particularly important since it is used as a nursery by several freshwater fish species. From personal observations, I have observed that the plant has quite an important capacity to propagate with cuttings, unlike the pondweed which does not survive without a consequent substratum and without intact roots.

Presently, macrophytes are considered by the public to be an invasive species, aesthetically displeasing, or at least useless plants. Thus, under the pressure of the public, they are harvested and treated as urban waste with the Environmental Guard to the lake, and Administration issuing fines when macrophytes are not harvested and deposed of properly. Such practices are not recommended by biologists, biochemists and even agricultural engineers. Their arguments are presented below. The areas colonised by aquatic macrophytes could be put to use according to integrated management techniques gaining economic benefits from the sale of macrophytes to agricultural users. There are also economic benefits from the sustainable and integrated management of the lake ecosystems. By conserving patches of macrophytes for repopulation and for the protection of alevins and hatchlings, as many aquatic birds nest on urban lakes. Their economical potential is capitalised by using the plants as fertilisers and crop protection, as well as a nutritional supplement for farm animals. Last but not least, the ecological importance of aquatic macrophytes is generally known and was demonstrated also in the case of the Tineretului Lake of Bucharest. The macrophytes influence the physical and chemical parameters of the lake water, as well as contribute to the local micro and macrofauna. The lake is used for fishing, populated with perch, pike, carp, Prussian carp, bighead carp, silver carp, catfish and common rudd. Significant mallard and herring gull populations use the lake as a nesting site along with families of little grebe and common moorhen, which are attracted by the presence of the submerse vegetation. 


\section{MATERIAL AND METHODS}

For the present paper the documentation elaborated by the international authority in the field, the Food and Agriculture Organisation (FAO), as well as international studies regarding the ecology of the two macrophyte species are reviewed.

Own observations and communications with personnel administering the Tineretului Lake were also used to evaluate the impact of the macrophyte presence on the macrofauna.

Samples of zooplankton and alevins were collected during 2007 and 2009 from Tineretului Lake. Also, physical and chemical readings such as water and air temperature, transparency, dissolved oxygen and carbon dioxide, bicarbonate, nitrate, nitrite, phosphate ions and ammonia were measured in Tineretului Lake during the same period.

\section{RESULTS}

\section{Economical advantages of using aquatic macrophytes}

Reimer and Toth (1969), performed detailed chemical analysis on several species of Potamogeton and Myriophyllum, as well as on species of Nymphaeaceae, in order to determine the nutrient uptake potential of every species. Ample variations of the chemical composition were registered, both intra and interspeciphically. It is notable that these samples were taken on plants coming from the same water tank in New Jersey, USA. The averages are presented in table number 1.

The rich content of potassium, iron, phosphorus and trace elements suggests using these plants as fertilisers. Putrefying weeds have historically been used in poor agricultural areas as fertilisers. It is a simple and efficient use for these plants. Aquatic macrophytes harvested and then naturally desiccated on dry land have the advantage that their seeds and roots will not compete with the crop, as is the case with weeds. This source of minerals and organic nutrients is recommended due to low harvesting costs and treatment, especially for areas in which these plants are abundant and artificial fertilisers are rare and expensive (Kamal and Little, 1970).

In horticulture, applying thick layers of last year's aquatic plants on the soil early in the spring (previously dried and partially decomposed) will inhibit the growth of weeds and maintain moisture in the soil. Also, the aquatic plants can be used for mulching. When decomposition is finished, all nutrients are absorbed into the soil and the fibrous remains can be incorporated in the soil as a supplement of organic matter with the added benefit of aerating clay-rich soil.

When cultivated land is far from the water bodies, drying the plants on shore in advance will minimise transportation and operating costs by diminishing weight and volume. Another option is composting the aquatic plants, at the end of this process the product being less voluminous, is easier to transport. Some authors propose burning the dry plants and using the ash as fertiliser, since it contains a higher concentration of minerals, except nitrogen, and it weighs only a fraction of the original wet-plant mass. But in climate conditions that do not allow the complete dehydration of the plants prior to burning this operation can be inconvenient.

Reimer and Toth (1969) stress that, "The analytical data indicate that species of Myriophyllum and Potamogeton contain sufficient total $\mathrm{N}$ for decomposition. Partial drying of the cut plants before composting, however, will be necessary to reduce anaerobic decomposition to a minimum. The final composts prepared from the aquatic plants probably will contain fairly high amounts of minor elements, especially Fe, Mn and Zn, which may be beneficial (Tab. 1). It is believed that the composts will need the addition of extra P and K.” 
Table 1: Average concentrations of minerals in plants of the Potamogeton genera, including $P$. amplifolius, $P$. crispus, $P$. natans, $P$. pulcher and $P$. pectinatus, and the Myriophyllum genera, including $M$. heterophyllum and $M$. spicatum, after Reimer and Toth (1969).

\begin{tabular}{|c|c|c|}
\hline Element & Potamogeton spp. & Myriophyllum spp. \\
\hline & \% dry weight & \% dry weight \\
\hline $\mathrm{Na}$ & 0.56 & 1.15 \\
\hline $\mathrm{K}$ & 2.28 & 1.75 \\
\hline $\mathrm{Ca}$ & 3.38 & 1.38 \\
\hline $\mathrm{Mg}$ & 0.33 & 0.32 \\
\hline $\mathrm{Fe}$ & 0.73 & 2.10 \\
\hline $\mathrm{Mn}$ & 0.16 & 0.76 \\
\hline $\mathrm{P}$ & 0.33 & 0.43 \\
\hline $\mathrm{S}$ & 0.44 & 0.29 \\
\hline $\mathrm{N}$ & 2.51 & 2.81 \\
\hline $\mathrm{Cl}$ & 1.18 & 1.86 \\
\hline $\mathrm{Cu}$ & 33.9 & 35.0 \\
\hline $\mathrm{Zn}$ & 82.9 & 379.0 \\
\hline & $\mathrm{ppm}$ & $\mathrm{ppm}$ \\
\hline
\end{tabular}

Thompson and Hartwig (1973) also reported the successful use of Myriophyllum spicatum and $M$. heterophyllum as soil fertilisers. Plants were prepared by being cut and dried.

Other uses of these plants exist in places like Canada, the United States, China, India and Egypt, namely as horticulture and greenhouse-crops manure, fertilisers for potted plants, winter fertilisers for orchards and turf, and foliar fertilisers. These practices are employed by individuals, as well as by small-scale producers, with excellent results and are encouraged by receptive eco-oriented markets in Western Europe and North America.

The manufacturing costs for ecological aquatic-plant-based fertilisers are much lower than that of artificial fertilisers. When combined with the large interest in the western market, combined with the significant demand for retail sales of this type of product. It points to a particularly noteworthy profit share for the businesses interested in this market segment. Ecological fertilisers have even generated a fashion trend in Canada called the Lasagna Garden trend. The "algae" powder contains several trace elements in higher concentrations than are found in artificial fertilisers with the main nutrient ratio being N-K-P $=(1.5-0.2-1.3)$. The powder is used to stimulate growth in plants and increase their hardiness. It is mixed with the soil in spring, or incorporated in the compost. Taking in consideration the large concentration of oligoelements it is recommended to be used moderately, in a dosage of $1 \mathrm{~kg} / 100 \mathrm{~m}^{2}$.

Foliar fertilisation consists in vaporising fertiliser directly on to plant leaves, preferably on the underside of the leaves. The effect of this fertilisation method is very rapid, since the nutrients are immediately assimilated and used by the plants. Foliar fertilisation is particularly useful after plant stress (transplantation, hail, wind, cold, heat, and drought). Or in the case of severe nutritional deficiency, it is best applied as soon as the need is recognized.

Foliar fertiliser is better absorbed when vaporised into fine drops and applied early in the morning or in the evening. During these periods the air is cooler and more humid, favouring the opening of stomata. 
The most common foliar fertilisers used are either liquid or soluble. Fertilisers based on algae, plants or fish are particularly effective and they are specifically suggested for shortterm deficiencies in plants, and in commercial centres and flower shops where vegetation stagnates and plants don't flower due to low natural light, air currents, or plant refrigeration during transportation. The use of natural foliar fertilisers significantly cuts losses for this commercial segment between the producer and the final beneficiary.

Easley and Shirley (1974) consider that invasive aquatic plants should be harvested by mechanised means instead of treating them with specialised herbicides. This allows the plants to be acceptable for animal consumption. The study described the annual evolution of the mineral nutrient content in six macrophyte species sampled once and twice per month: Hydrilla verticillata (water thyme), Eichhornia crassipes (common water hyacinth), Ceratophyllum demersum (hornwort), Potamogeton pectinatus (sago pondweed), Vallisneria americana (eelgrass) and Najas guadalupensis (water nymph). Table number 2 presents the minimum and maximum concentrations of minerals in these plants compared to the daily needs for a $300 \mathrm{~kg}$ calf for the same elements. For $\mathrm{Ca}, \mathrm{Mg}, \mathrm{Na}, \mathrm{Fe}$ and $\mathrm{Mn}$ these needs are largely met.

Table 2: Maximum and minimum concentrations of nutrients in aquatic macrophytes and percentages of the daily requirements of a $300 \mathrm{~kg}$ calf of the same nutrients contained in one kg of dry mass of macrophytes - according to Easley and Shirley (1974).

\begin{tabular}{|c|c|c|c|c|c|c|c|c|c|}
\hline & \multicolumn{9}{|c|}{ \% concentration of animal requirements in one kg dry weight } \\
\hline Plants & $\mathrm{Ca}$ & $\mathrm{P}$ & $\mathrm{K}$ & $\mathrm{Mg}$ & $\mathrm{Na}$ & $\mathrm{Fe}$ & $\mathrm{Cu}$ & $\mathrm{Zn}$ & $\mathrm{Mn}$ \\
\hline $\begin{array}{l}H . \\
\text { verticillata }\end{array}$ & $\begin{array}{l}300- \\
600 \\
\end{array}$ & $10-26$ & 50 & $\begin{array}{c}100- \\
160 \\
\end{array}$ & $\begin{array}{l}100- \\
200 \\
\end{array}$ & $\begin{array}{l}70- \\
140 \\
\end{array}$ & 63 & 33 & $\begin{array}{l}100- \\
200 \\
\end{array}$ \\
\hline $\begin{array}{l}\text { E. } \\
\text { crassipes }\end{array}$ & 85 & $10-26$ & 82 & $\begin{array}{c}100- \\
160 \\
\end{array}$ & $\begin{array}{l}100- \\
200\end{array}$ & $\begin{array}{l}70- \\
140\end{array}$ & $5-21$ & 33 & $\begin{array}{l}100- \\
200\end{array}$ \\
\hline $\begin{array}{l}\text { C. } \\
\text { demersum }\end{array}$ & $\begin{array}{c}300- \\
600 \\
\end{array}$ & $10-26$ & 50 & $\begin{array}{l}100- \\
160 \\
\end{array}$ & $\begin{array}{l}100- \\
200\end{array}$ & $\begin{array}{l}70- \\
140 \\
\end{array}$ & $5-21$ & $9-18$ & $\begin{array}{l}600- \\
200 \\
\end{array}$ \\
\hline $\begin{array}{l}P . \\
\text { pectinatus }\end{array}$ & $\begin{array}{l}300- \\
600\end{array}$ & $10-26$ & 50 & $\begin{array}{c}100- \\
160\end{array}$ & $\begin{array}{l}100- \\
200\end{array}$ & $\begin{array}{l}70- \\
140\end{array}$ & $5-21$ & $9-18$ & $\begin{array}{l}600- \\
200\end{array}$ \\
\hline $\begin{array}{l}V . \\
\text { americana }\end{array}$ & $\begin{array}{l}300- \\
600\end{array}$ & $10-26$ & 25 & $50-80$ & $\begin{array}{l}100- \\
200\end{array}$ & 68 & $5-21$ & $9-18$ & $\begin{array}{l}100- \\
200\end{array}$ \\
\hline $\begin{array}{l}N . \\
\text { guadalupensis }\end{array}$ & $\begin{array}{l}300- \\
600 \\
\end{array}$ & $10-26$ & 50 & $50-80$ & $\begin{array}{l}100- \\
200\end{array}$ & $\begin{array}{l}70- \\
140 \\
\end{array}$ & $5-21$ & $9-18$ & $\begin{array}{l}100- \\
200 \\
\end{array}$ \\
\hline
\end{tabular}

Shirley et al. (1971) analysed macrophytes of the genera Hydrilla, Ceratophyllum, Potamogeton, Chara and Vallisneria sampled from lakes, rivers and dikes. Linn et al. (1975) analysed the nutrient content of 21 aquatic plants. The authors concluded that these plants can be a useful food source for farm animals due to the high protein content and low, raw fibre content, thus indicating a high nutritional value. Also, the estimated contents of hemicelluloses, cellulose and lignin suggest that most of the macrophytes are highly digestible.

A fermentation study was performed on a mixture of 50\% Myriophyllum exalbescens, 30\% Ceratophyllum, 10\% Potamogeton pectinatus, 5\% Vallisneria, and 5\% other aquatic plants. The mixture was fermented (siloed) in a laboratory setting using different organic acids and additives. Corn seeds and triturated alfalfa were also fermented in separate silos. The respective silos were analysed and measured and the following observations were made: 
i. the dry matter in the aquatic plants silo was comparable with the one in the alfalfa silo, measuring 33.3 versus $32.3 \%$ respectively;

ii. all acid silos treated had less protein contents compared with the untreated ones, indicating a loss of protein mass through siloing;

iii. the ash content in the aquatic plant silo was high (47.5\% in average);

iv. no major chemical discrepancies were recorded, including the organic matter content, when in the aquatic plant silos were added $5 \%$ corn or $75 \%$ alfalfa;

v. the formic acid was the most effective in reducing the occurrence of the butyric acid;

vi. adding alfalfa on sterilised aquatic plant silo led to the formation of a more acceptable silo than if alfalfa was added to unsterilized aquatic plants.

Little (1968 a, b) recommended the use of aquatic plants as fodder for pigs. These omnivorous animals have no problem accepting high water content in their food. Other authors reviewed by the FAO document tested aquatic plants in pig food and reported that the animals were reluctant to eat the plants as such, yet they accepted the aquatic plant ash mixed with other feed.

Other important substances highly concentrated in aquatic plants are the xanthophylls. Bailey (1965) mentions specifically Ceratophyllum sp., Elodea densa and Myriophyllum exalbescens. He states, "The feed ingredient industry is constantly alert for new ingredients or new additives which can improve the efficiency of the finished feed or can effect savings without detracting from the quality of the feed. In the above instance, we were impressed by the xanthophylls content of these dehydrated aquatic plants. Xanthophylls are oil-soluble carotenoid pigments found in some plants. There are many different xanthophylls. Some are effective in imparting a yellow colour to the skin of chickens and in darkening the yolk colour of eggs used mainly for the egg-breaking industry. Other xanthophylls are ineffective in this respect. Couch J. B. and associates of Texas A and M University recently reported that xanthophylls in these aquatic plants gave good colouration to egg yolks, and rated xanthophylls in aquatic plants about equal to that in alfalfa meal in this respect." (in FAO Handbook).

Lange (1965) describes harvesting Myriophyllum, Elodea and Ceratophyllum in northeastern Texas. The weeds were processed through a conventional alfalfa dehydration mill to produce $40 \mathrm{t}$ of dried meal. This was sent to Texas $\mathrm{A}$ and $\mathrm{M}$ for a stock feeding programme which involved poultry, pigs and cattle. The results gave a strong indication that the potential for commercial production and marketing lay in the direction of a poultry feed supplement for egg yolk and broiler pigmentation. This was based on xanthophylls values in excess of 660 $\mathrm{mg} / \mathrm{kg}$, protein in the $20 \%$ range and a low fibre of $10-15 \%$.

Regarding the use of Myriophyllum spicatum and filamentous algae, Bruhn et al. (1975) confirms that the birds are considerably efficient in assimilating proteins and xanthophylls from these plants.

Creger et al. (1963) analysed a dehydrated mixture of three macrophytes and concluded that it contained $17.9 \%$ proteins, $11 \%$ gross fibres and $440 \mathrm{mg}$ xanthophylls $/ \mathrm{kg}$. Concentrations of 5, 10, 15, 20 and 25\% administered in poultry fodder produced NEPA numbers of 3, 4.5, 5.5, 6.3 and 6.8 respectively when incorporated into milo-soybean oil meal basal diet and fed to laying hens. Levels of 10 and $20 \%$ of dehydrated alfalfa meal, which analysed 20\% protein and $500 \mathrm{mg}$ xanthophylls per kg, produced NEPA numbers of 4.75 and 6.1 under similar conditions. From these data it can be concluded that the naturally occurring 
xanthophylls found in a dehydrated blend of three species of flowering aquatic plants were biologically available and produced egg yolks of NEPA numbers similar to those which resulted from the feeding of approximately equivalent levels of xanthophylls from dehydrated alfalfa meal (FAO, 1979).

Linn et al. (1975) studied the digestibility rate in sheep for the same aquatic plants, both in a desiccated and fermented (siloed). They concluded that dried Myriophyllum exalbescens and Potamogeton pectinatus are not palatable for lambs (less than $600 \mathrm{~g}$ dry mass consumed daily).

The results of this study suggest the palatability of aquatic macrophytes can constitute a limiting factor in their use as fodder for ruminants. Desiccation and silo fermentation did not appear to be satisfactory methods in improving palatability. Unfortunately, this study was not confirmed by the findings of other scientists, its conclusions still need to be validated against other animal groups accustomed to consuming unfermented fodder.

Regarding economically important fish species that live in lakes or smaller European bodies of water, they all consume aquatic vegetal matter at least at one stage of their life cycle. Prejs (1984) listed 15 species, such as Leuciscus idus, Rutilus rutilus and Scardinius erythrophthalmus as being predominantly herbivorous; Abramis brama, Blicca bjorkna, Leuciscus cephalus, Carassius carassius, Gobio gobio, Tinca tinca and Cyprinus carpio consume vegetation in small quantities while Rhodeus sericeus amarus, Alburnus alburnus, Perca fluviatilis and juvenile Esox lucius are occasional consumers. Primarily herbivorous fish such as $R$. rutilus and $S$. erythrophthalmus, typically consume most of the submerged macrophytes found in large enough densities, with a preference for macrophyte species with soft tissues.

Bănăduc (2003), Bănăduc and Bănăduc (2008) and Bănăduc et al. (2011) revealed fish species in the Romanian national territory which include in their diets vegetals: Alburnoides bipunctatus, Barbus meridionalis, Squalius cephalus, Romanogobio albipinnatus vladykovi, Barbus barbus, Chondrostoma nasus, Gobio gobio, Pseudorasbora parva and Rhodeus sericeus amarus.

Ctenopharyngodon idella (snake-head fish) was introduced in Romanian fresh waters to help control water plants, but also for human consumption. In the United States after 1963 this species became very controversial due to the ecological consequences of its introduction. Research carried out in Europe and Asia, and in Petr (2000) starting in the 70's, documented that the Potamogeton species are a favourite food, or at least among the most consumed species of macrophytes in C. idella's diet, as well as in the diet of his common carp hybrids and in the diet of Hypophthalmichthys nobilis. Mehta et al. (1976) in Petr (2000) demonstrated that in India, Potamogeton sp. is preferred by $C$. idella once the fish reaches at least $200 \mathrm{~g}$.

Fowler and Robson (1978) in Petr (2000) mention cases in which C. idella (217 g average weight) forming fish stocks of $116-688 \mathrm{~kg} / \mathrm{ha}$ went from a preferential diet of Potamogeton crispus to an unpreferential diet following the consumption of nearly the entire mass of $P$. crispus plants, the plant needing one year to recover once the fish was removed from the depleted reservoir.

Such uses for macrophytes, both field crop fertilisation and mulching, as well as food sources or supplements for farm animals from fish and poultry to pigs and bovines, generated remarkable economic results, which were well documented and recommended as Best Agricultural Practices by FAO since the 70's. 


\section{Ecological advantages of using aquatic macrophytes}

On one side, the submerged aquatic macrophytes are substrata and habitat for incredibly complex and varied communities, but in uncontrolled conditions, a rich macrophytic lacustrine ecosystem has the tendency to self-regulate slowly, eventually evolving into overgrowing and warping.

On the other side, by the nature of vascular plants, the macrophytes of lotic ecosystems act as an efficient filter for nutrients of natural origin (excretion products and by-products), or artificial origin (fertilisers and pesticides historically administered in excess). In Bucharest more than 50-years-worth of these pesticides and fertilisers have reached the ground water and rivers that feed the urban lakes and the Colentina River, which are contaminated with sewage effluents introduced either intentionally or accidental by the metropolitan sewage network.

Howard-Williams (1981) describes an experiment in which $4.5 \mathrm{~m}^{2}$ sized pans were planted in a thick Potamogeton pectinatus population and were supplied with weekly inputs of $\mathrm{NaNO}_{3}$ and $\mathrm{KH}_{2} \mathrm{PO}_{4}$ in four different concentrations (max. 1,000 mg nitrogen/week and 100 $\mathrm{mg}$ phosphorus/week) during a period of 15-23 weeks.

The most obvious outcome was the development of dense populations of filamentous algae. Nevertheless, there was no parallel development of planktonic algae and the levels of chlorophyll remained low during the entire period of the experiment. Nine weeks later, for all levels of nutrients administered, the macrophytic community removed the entire administered quantity of nitrogen and phosphorus. Experiments with the isotope $\mathrm{P}_{32}$ demonstrated that a large part of the added phosphorus was being absorbed in two hours by the filamentous algae growing as epiphytes on the macrophytes. The nitrogen and phosphorus concentrations per unit of dry mass of algae, macrophytes and sediment increased significantly only for the most concentrated fertilising treatment.

The above mentioned experiment shows that the areas with a large density of submerged aquatic macrophytes, together with their associated epiphytic algae (mainly Cladophora sp.), are very efficient and useful nutrient filters for the purification of stagnant or slowly running surface waters.

Scarsbrook and Davis (1971) measured the growth of five aquatic plants in well water to which sewage effluent had been added; this was recorded together with their uptake of nitrogen, phosphorus and potassium. The plants were Eichhornia crassipes (water hyacinth), Alternanthera philoxeroides, Potamogeton crispus, Egeria densa and Najas flexilis. The tests were in plastic pools $66 \mathrm{~cm}$ deep and $2.7 \mathrm{~m}$ in diameter, containing no soil. A mixture of all the plants was put in each pool. Half the pools had $25 \%$ sewage effluent, the others had well water only. In the latter pools all the test plants died except $A$. philoxeroides, but its growth was stunted and unhealthy. In the sewage-treated pools, by the end of 11 weeks the water hyacinth had dominated all the other species and covered $71 \%$ of the water surface. The next vigorous level was A. philoxeroides, though its growth was much less than that of the water hyacinth. The other test plants did not grow sufficiently in the face of the competition to justify harvesting. The results are shown in table number 3.

"The authors concluded that water hyacinth could be usefully employed to extract nutrients from sewage." (FAO, 1979).

The following results from the survey of water quality in the Tineretului Lake of Bucharest, Romania come from the period of October 2007 to August 2008, which includes the vegetation season of the aquatic macrophytes (Potamogeton crispus mainly and Myriophyllum spicatum) and the harvesting of the entire macrophyte community during June and July 2008. These results have also been largely presented in Hurdugan-Irimia (2008). 
Table 3: Growth over 23 weeks (April-October - g dry weight) of five aquatic plant species treated with well water and sewage effluent. From Scarsbrook and Davis (1971) in FAO (1979); includes weight of plants harvested at 11 weeks.

\begin{tabular}{|l|c|c|c|}
\hline \multirow{2}{*}{ Plant } & \multirow{2}{*}{$\begin{array}{c}\text { Initial } \\
\text { weight }\end{array}$} & \multicolumn{2}{|c|}{ Harvested weight } \\
\cline { 3 - 4 } E. crassipes & 2.0 & Well water only & $25 \%$ sewage effluent \\
\hline A. philoxeroides & 0.6 & 7.9 & 736.6 \\
\hline P. crispus & 0.5 & 0.9 & 20.4 \\
\hline E. densa & 0.2 & 0.0 & 4.7 \\
\hline$N$. flexilis & 0.1 & 0.0 & 0.0 \\
\hline
\end{tabular}

During the maximum vegetation season the differences between the source area and the outlet point are dramatic, with up to a 10-fold decrease of the $\mathrm{CO}_{2}$ concentration in the water. These differences disappeared when the vegetation was removed.

The oxygenating effect of the macrophytes and of the epiphytic filamentous algae is visible in the difference between the $8 \mathrm{mg} / \mathrm{l}$ concentration of the dissolved oxygen in the sources area (at the origin of the lake) and $12.5 \mathrm{mg} / \mathrm{l}$ at the outlet point during the vegetation period. The same parameters registered $10.5 \mathrm{mg} / \mathrm{l}$ dissolved oxygen in the sources area versus $11 \mathrm{mg} / \mathrm{l}$ in the outlet point once the vegetation was removed.

The same goes for the absorption of the $\mathrm{CO}_{2}$ from the lake water by the macrophytes and the epiphytes in the analysed period. There was also a decrease of the concentration of carbonate ion in the water through the effect of the biological pump of $\mathrm{CO}_{2}$ modifying the balance of the naturally present carbonates in the lake. The pump effect increased the supplementary support offered by the plants, especially $P$. crispus, for the deposit of the Ca and $\mathrm{Mg}$ carbonates on the macrophytes.

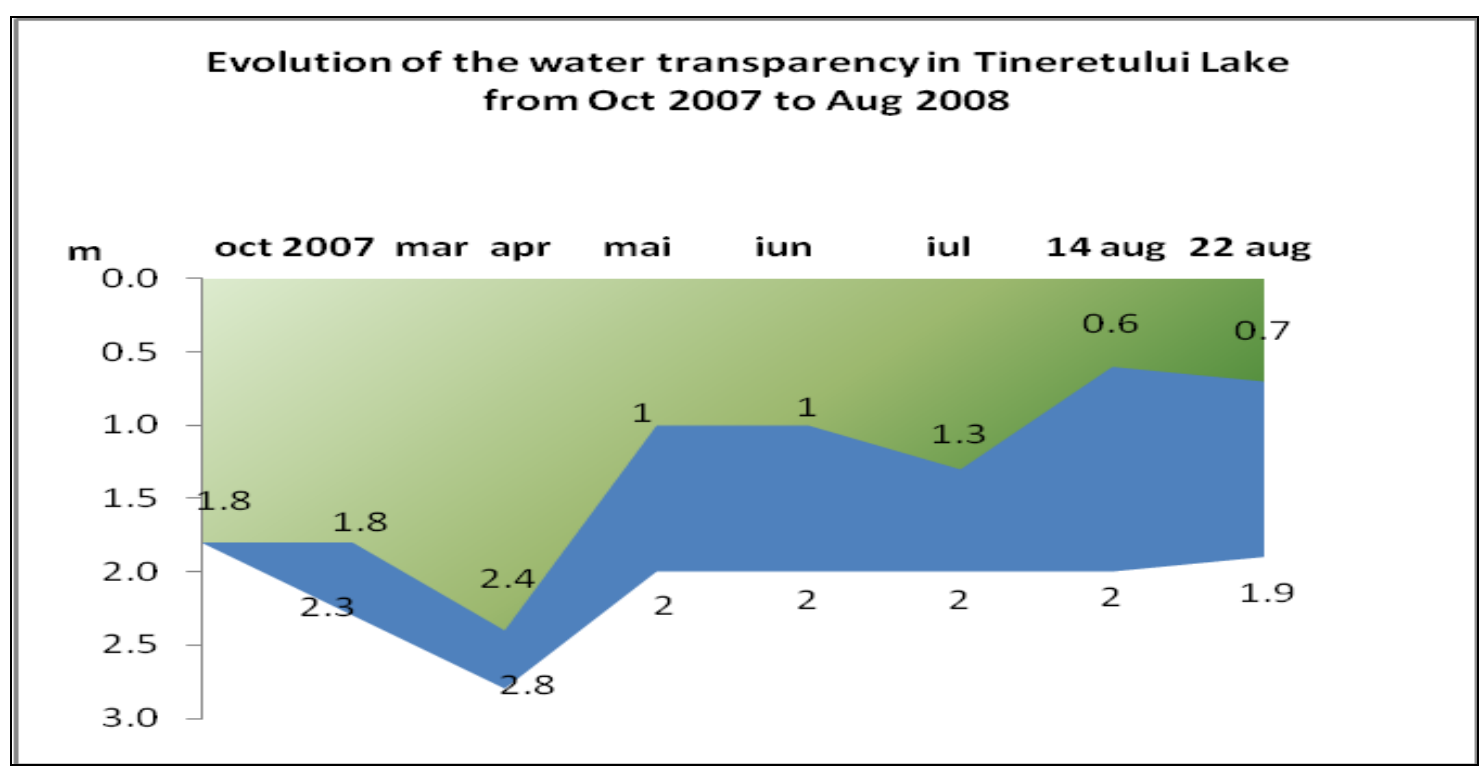

Figure 1: The water transparency evolution in the Tineretului Lake during October 2007 -

August 2008. The green polygon represents the Secchi disk measured transparency.

The sum of the green and blue polygons represents the measured depth in the sampling point

(Hurdugan-Irimia, 2008). 
Regarding nitrates, nitrites and ammonia, the main excretion products of the lake fauna, there is a clear discrepancy between the constant concentrations of these products in the lake water during the period before the harvest of the macrophytes, followed by a large increase of the same parameters' values after the harvest; up to three times more than the regular concentration. Also, differences between the sources area of the lake and the outlet point are noticeable in the concentrations of nitrogen compounds (from $0.8 \mathrm{mg} / \mathrm{l}$ nitrates in the sources area to $0.5 \mathrm{mg} / \mathrm{l}$ at the outlet and from $89 \mathrm{mg} / \mathrm{l}$ in the sources area to $50 \mathrm{mg} / \mathrm{l}$ at the outlet) during the vegetation season, marking the importance of the macrophyte role in water purification.

The ammonia is not directly taken up by macrophytes but it is decomposed by Nitromonas bacteria into nitrites. Its concentration remained constant from the origin to the outlet of the lake, yet it varied in time, reaching dangerous levels for fish after the removal of the submerged macrophytes.

"All the analyzed parameters, nitrites, nitrates, dissolved oxygen and carbon dioxide, ammonia and transparency (Fig. 1) have presented optimum values for the MarchApril period, correlated with the period of macrophytic vegetation growth which reached its maximum development in height and density at the end of April. After the harvesting period from May 2008, the water quality deteriorated significantly and the phytoplankton received the necessary light, temperature and nutrient stimulation in order to bloom massively. The evolution of the physical and chemical indicators of the water quality have closely followed the presence of the macrophytic species, especially that of the Potamogeton crispus.” (Hurdugan-Irimia, 2008)

\section{Harvest and elimination - biological control}

The use of rakes, chains, and mechanical reapers to remove the submerged aquatic vegetation is known to be both costly and laborious, yet the results are not considered satisfactory. For instance, mechanised controls generally engendered thicker plant populations during the next season due to the reduced competition for nutrients and light, according to Neel et al. (1973) in Petr (2000). Also mechanical removal leads to the occurrence of morphologically smaller individuals (Engel, 1984, in Petr, 2000) a phenomenon personally witnessed in August 2008 in Tineretului Lake, Bucharest.

Due to the hydrochoric spreading of these plants, their cutting and harvesting, even up to three times in a year, will never completely and definitively remove the species from the ecosystem.

Nature has a way, Ctenopharyngodon idella is the fetish species of phytophagous fish introduced in still waters for the biological control of the biomass of submerged macrophytes. According to research led by Mitzner in 1978, in Petr (2000), this fish species was responsible for the reduction of the July biomass in Potamogeton crispus and Potamogeton nodosus from $1,400 \mathrm{~g}$ dry weight $/ \mathrm{m}^{2}$ to $24 \mathrm{~g}$ dry weight $/ \mathrm{m}^{2}$ in four years, but three years later, the $C$. idella biomass decreased to the level of the second year of introduction.

Ctenopharyngodon idella is a voracious consumer of Potamogeton, this macrophyte species being its favourite in pilot farms. Yet they need to be controlled by predators in order not to exterminate the plants completely and degrade the local ecosystem since the partial control of the plants is very difficult to obtain due to the gluttony of the snakehead carp. 
Since the adverse effects of the Ctenopharyngodon idella were noticed after its introduction in lakes dedicated to sport fishing and leisure, mainly due to overpopulation, research concentrated on the use of sterile diploids and triploids of Ctenopharyngodon idella in order to control aquatic macrophytes (Bowers et al., 1987, in Petr, 2000). Besides, these fish retain up to $90 \%$ of the dissolved phosphorus from administered pesticides and fertilisers present in the water according to Chapman and Green (1987). Wiley et al. (1984) created special computer models of fishery management demonstrating that the triploid Ctenopharyngodon idella is economically more efficient in controlling aquatic vegetation than the use of pesticides.

Other species that can be used to control macrophytes are waterfowl, wild or domestic: ducks, geese, as well as swans and moorhens, all of which are present in large numbers in Bucharest lakes. For instance, the author personally identified in 2006-2008 around 50 pairs of mallards Anas plathyrhynchos on Tineretului Lake in central Bucharest alone, as well as a family of nine mute swans Cygnus olor, and four pairs of moorhens Fulica atra, etc. All these species were consuming large quantities of aquatic vegetation, especially soft-tissues plants. Other waterfowl species consume the grains and/or fruits of aquatic macrophytes, thus controlling their spread, especially for Potamogetonaceae, Cyperaceae and Polygonaceae, Potamogetonaceae being the favoured food source. Grazing significantly affects biomass, as well as the growth of submerged macrophytes.

Waterfowl are particularly efficient in the control of aquatic macrophyte biomass, reaching consumptions up to $40 \%$ of the live biomass of Potamogeton pectinatus in Manitoba marshy delta, Canada (Anderson and Low, 1976, in Petr, 2000), 30\% of the live biomass of P. filiformis in Loch Leven, Scotland (Jupp and Spence, 1977, in Petr, 2000) and around $50 \%$ of the live biomass of a mixed assemblage of submerged macrophytes in Tipper Grund, Denmark (Kiorboe, 1980, in Petr, 2000).

The success of waterfowl in controlling the aquatic macrophytes is also demonstrated by figure number $2 \mathrm{a}$, b, showing the macrophyte consumption ratios for rudd (S. erythrophthalmus) and waterfowl in Zwemlust Lake, Holland, where the estimated annual consummation of macrophytes by coot (Fulica atra) was calculated as 30 to 1,200 $\mathrm{kg} /$ year, compared to the rudd, situated between 170 and $360 \mathrm{~kg} / \mathrm{year}$ (Van Donk and Otte, 1996, in Petr, 2000). Mitchell and Perrow (1998) suggest that the birds have a major impact on the dynamics of the aquatic vegetal biomass in temperate areas only during periods of weak biomass production, either in early spring when the biomass is still at low levels, or late in the autumn when the primary production slows its rhythm or stops. This was noticed by Olofsson (1991) for Potamogeton crispus in the case of Stigholm Lake of Denmark.

These "gentle" methods to control the macrophyte biomass produced in a lake are preferable to mechanised or chemical controls. "Gentle" methods of control are part of the old and long-tested mechanisms of Nature, which always tend toward the optimum regulation of physical, chemical or biological resources. These methods permit the maintenance of a particularly clean lake (in terms of transparency, purity, richness, biological diversity) as a whole. Additionally, these methods are also the cheapest and the most ecological and aesthetically pleasing. 


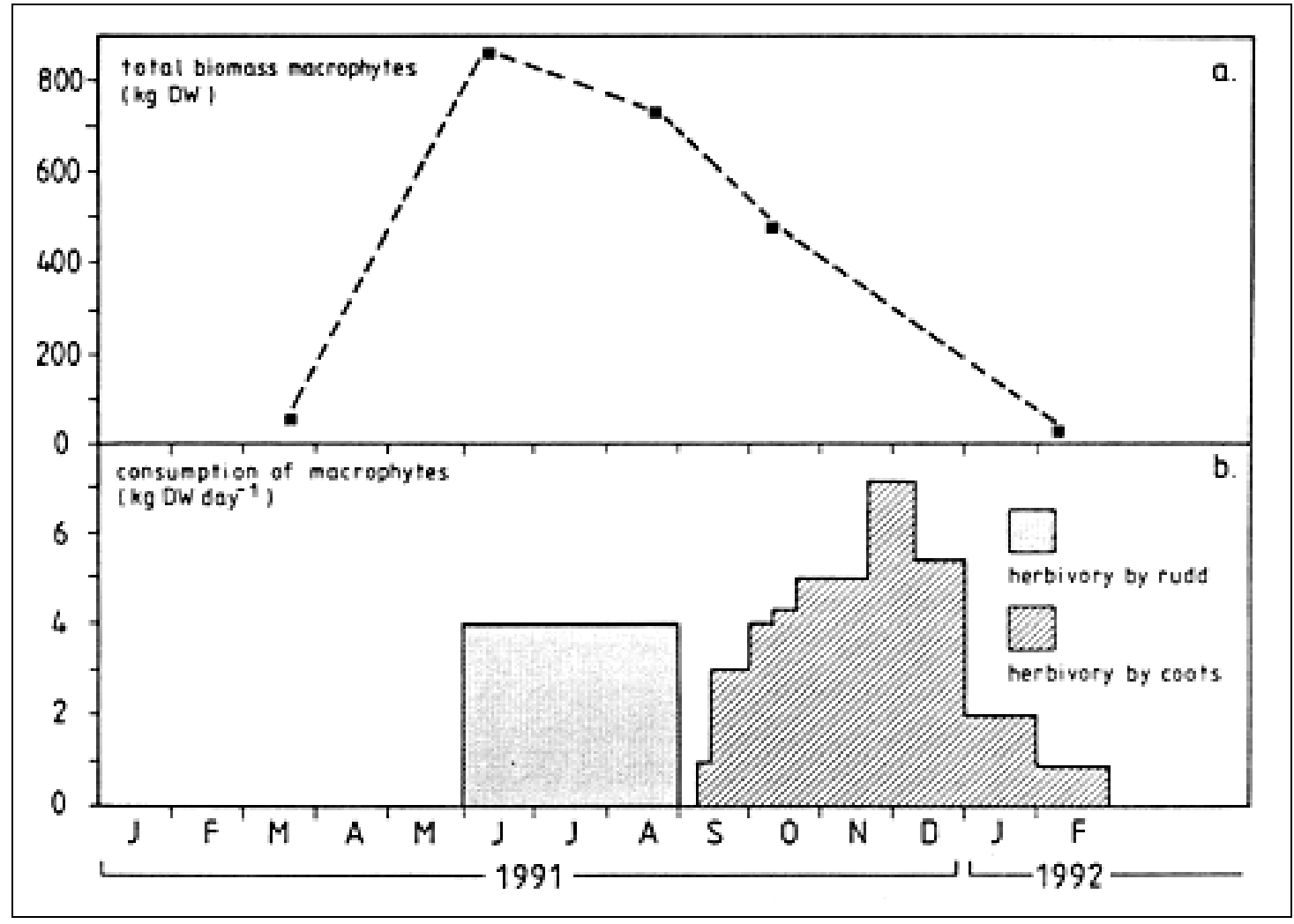

Figure 2: a) Total biomass of aquatic macrophytes (dry weight kg) in Zwemlust Lake estimated in March, June, August, October 1991 and February 1992;

b) Estimations of the consummation (dry weight kg of macrophytes/day) by rudd and coots in Zwemlust Lake (May 1991 - February 1992) from Van Donk et al. (1994).

\section{CONCLUSIONS}

Presently, the management of the lakes in the area of Bucharest oscillate between two alternatives. At one end of the scale are lakes intensively used for fishing, administered according to a pseudo-economical logic excluding the ecological reasoning and means, in which the ecosystems are out of balance and frail. One such example is Herăstrău Lake, where during the hot summer of 2007, the economically interesting populations of fish were severely affected by hypoxia and the lake water registered toxic levels of ammonia and nitrogen compounds (personal observations) while zooplankton invertebrates disappeared very early in the season (almost azoic, negative for Cladocerans samples in October 2007). At the other end of the scale are lakes abandoned to the good work of Nature, such as Văcăreşti, an oasis for waterfowl and other water-related fauna, which are threatening to disappear due to real-estate projects and the natural overgrowth of reed and cattails.

Somewhere in the middle are lakes whose management, during certain periods of time, were cared for through respectful and ecological approaches. For example Tineretului Lake during 2004-2007. Here, the fishery and leisure facilities practiced sustainable development. The lake water had a superior quality compared to tap water during winter, and the ecosystem was balanced and stable. It was an oasis for 23 species of fish and birds protected by the Bern Convention and CITES Convention. Not to mention the lake is also home to 48 species of phytoplankton, 46 species of epiphytes, two species of macrophytes, 15 species of cladocerans, 
at least six species of aquatic insects, two species of molluscs, nine species of fish, three species of amphibians, two species of chelonians, and 19 species of birds (Hurdugan-Irimia, 2013). During the same reference period for Herăstrău Lake (July-October 2007), Tineretului Lake zooplankton were numerous, the water had a good quality and the fish population was not affected by heat, nor a lack of oxygen (personal observations).

The same lake stands as proof of the negative effects that the total elimination of the submerged macrophytes can have. After the harvest in May 2008, the water quality deteriorated rapidly and the phytoplankton, stimulated by light, high temperatures and lack of competition for nutrients, had a massive bloom. This food source was not appropriate for the ducklings that year, many of which died (more than 50\% mortality for some mallard families that year, according to the observations of the lake administration). Also, due to the lack of the shelter usually provided by the macrophytes at that time of year, many of the chicks and ducklings were attacked by pike and catfish (near 30\% mortality for some families, according to the observations of the lake administration).

The submerged aquatic macrophytes are a part of the lacustrine ecosystems, both a cause and a symptom of their quality. A lotic ecosystem, whose equilibrium is characterised by a high degree of homeostasis, requires a reasonable surface to be occupied by aquatic vegetation in order to support the macrophytophylous species, either invertebrates or economically interesting fish and waterfowl.

Considering that the ground water nape and surface waters that feed into the fishing waters of the Câmpia Română are heavily charged with nitrates from 50 years of intensive agriculture, such surface coverage is indispensible for maintaining proper water quality.

The vegetation patches can also contribute significantly to an aesthetic look of the water body, providing a pleasant sight as well as transparent, clean water and a rich fauna worthy of a civilised European metropolis, which the capital city of Romania aspires to.

If we consider all of these reasons, including a larger production of fish of all species in the lake, an economical valorisation of the harvested macrophytes from two-thirds of the lake surface for agriculture, horticulture and animal rearing, one would observe a proper example of integrated, successful management of urban lakes. In doing so, the logic shifts from winner-loser, to everybody wins way of thinking: the Lakes, Parks and Leisure Facilities Administration, the environment, the population, the city image and the future generations.

\section{REFERENCES}

1. Bailey T. A., 1965 - Commercial possibilities of dehydrated aquatic plants, Proceedings of the Annual Meeting of the Southern Weed Sciences Society, 18, 543-51.

2. Bănăduc D., 2003 - Contribuții la morfologia şi biologia speciilor genului Gobio (Gobioninae, Cyprinidae, Pisces) în România, PhD Thesis, 202. (in Romanian)

3. Bănăduc A. and Bănăduc D, 2008 - Trophic elements regarding the non-indigenous Pseudorasbora parva (Schlegel) 1842 fish species spreading success - Olt River Basin, a case study, Journal of Bioloy - Zoology, Edit. Academiei Române, 6, 185-196.

4. Bănăduc D., Oprean L., Bogdan A. and Curtean-Bănăduc A., 2011 - The analyse of the trophic resources exploitation by the congener species Barbus barbus and Barbus petenyi in the Târnava River Basin, Transylvanian Review of Systematical and Ecological Research, 12, Curtean-Bănăduc A. et al. (eds), Edit. “Lucian Blaga” ISSN 1841-7051, 101-110.

5. Bruhn H. D., Koegel R. G. and Livermore D. F., 1975 - Utilization of aquatic vegetation, Annual Meeting of the North Atlantic Region of the American Society of Agricultural Engineers, New York, 13. 
6. Chapman M. A. and Green V. D., 1987 - Zooplankton ecology, in Inland waters of New Zealand, (ed.) Viner A. B., Wellington, New Zealand, 225-263.

7. Creger C. R., Farr F. M., Castro E. and Couch J. R., 1963 - The pigmenting value of aquatic flowering plants, Poultry Science, 42, 1262-3 (Abstr.).

8. Easley J. F. and Shirley R. L., 1974 - Nutrient elements for livestock in aquatic plants, Hyacinth Control Journal, 12, 82-84.

9. Fowler M. C. and Robson T. O. 1978 - The effects of the food preferences and stocking rates of grass carp on mixed plant communities, Aquatic Botany, 5, 261-276.

10. Howard-Williams C., 1981 - Studies on the Ability of a Potamogeton pectinatus Community to Remove Dissolved Nitrogen and Phosphorus, The Journal of Applied Ecology, 18, 2, 619-637.

11. Hurdugan-Irimia O., 2008 - The influence of aquatic macrophytes (Potamogeton crispus, Myriophyllum spicatum) on physical and chemical parameters in Tineretului Lake, Bucharest, Oltenia, Studii şi comunicări, Ştiinţele Naturii, XXIV, 237-242.

12. Hurdugan-Irimia O., 2013 - Biodiversitatea cladocerelor din Lacul Tineretului, Bucureşti, PhD Thesis "A. I. Cuza" University of Iaşi, 276. (in Romanian)

13. Kamal I. A. and Little E. C. S., 1970 - The potential utilization of water hyacinth for horticulture in the Sudan, PANS, 16, 3, 488-966.

14. Lange S. R., 1965 - The control of aquatic plants by commercial harvesting, processing and marketing, Proceedings of the Meeting of the Southern Weed Sciences Society, 18, 536-42.

15. Linn J. G., Staba E. J., Goodrich R. D., Meiske J. C. and Otterby D. E., 1975 - Nutritive value of dried or ensiled aquatic plants, 1 Chemical composition, 2 Digestibility by sheep, Journal of Animal Sciences, 41, 1, 601-615.

16. Little E. C. S. (ed.)., 1968 a - Handbook of utilization of aquatic plants, Rome, FAO, Plant Production and Protection Division, PL:CP/20, 123.

17. Little E. C. S. (ed.)., $1968 \mathrm{~b}$ - Handbook of utilisation of aquatic plants, Review of universal literature, FAO Fisheries Technical Paper, 187, FAOUN, Roma, 176.

18. Mehta I., Sharma R. K. and Tuank A .P., 1976 - The aquatic weed problem in the Chambal irrigated area and its control by grass carp, in Aquatic weeds in south east Asia, Varshney C. K. and Rzoska J. (eds), The Hague, Netherlands, 307-314

19. Mitchel S. F. and Perrow F. R., 1998 - Interactions between grazing birds and macrophytes in The structuring role of submerged macrophytes in lakes, Jeppesen E., Sondergaard M., Sondergaard M. and Christofferson K., (eds), New York, Springer-Verlag, 175-196.

20. Olofsson L., 1991 - Retablering af undervandsvegetation i Stigsholm So - M.Sc. Thesis, National Environmental Research and Botanical institutes, Aarhus University, 85. (in Danish)

21. Petr T., 2000 - Interactions between fish and aquatic macrophytes in inland waters - FAO Fisheries Technical Paper, 396, FAOUN, Roma, 220.

22. Prejs A, 1984 - Herbivory by temperate freshwater fishes and its consequences, Environmental Biology of Fishes, 10, 281-196.

23. Reimer D. N. and Toth S. J., 1969 - A survey of the chemical composition of Potamogeton and Myriophyllum in New Jersey, Weed Science, 17, 2, 219-23.

24. Scarsbrook E. and Davis D. E., 1971 - Effect of sewage effluent on growth of five vascular aquatic species, Hyacinth Control Journal, 9, 1, 26-30.

25. Shirley R. L., Easley J. F. and Hentges J. F., 1971 - Toxic substances and chemical composition of hyacinths and other water plants, Annual Research Report of the Institute of Food and Agricultural Sciences of the University of Florida, Gainesville, Florida, 65 (Abstr.).

26. Thompson T. W. and Hartwig H., 1973 - Control of water milfoil in large Wisconsin lakes, Hyacinth Control Journal, 11, 20-30.

27. Van Donk E., Deckere E., Klein Breteler J. G. P. and Meulemans J. T., 1994 - Verhandlungen Internationale Vereinigung für theoretische und angewandte Limnologie, 25, 2139-2143.

28. Wiley M. J., Gorden R. W., Waite S. W. and Powless T., 1984 - The relationship between aquatic macrophytes and sport fishing production in Illinois ponds: a simple model, North American Journal of Fisheries Management, 4, 111-119. 